\title{
RAF1 Gene
}

National Cancer Institute

\section{Source}

National Cancer Institute. RAF1 Gene. NCI Thesaurus. Code C18338.

This gene is involved in cell growth, proliferation, differentiation and migration. It also plays a role in apoptosis. 